\title{
Effect of Petroleum oil on the germination, growth and yield of broad bean plants
}

\author{
H. El- Tantawy
}

and

\author{
A. El- Hilaly \\ Science Department, College of Basic Education \\ P.O. Box 34053, Adailya, Kuwait
} Hassan El- Tantawy and A. El- Hilaly. 2001. Effect of Petroleum oil on the germination, growth and yield of
broad bean plants. Taeckholmia 21(2): 269-282.

The effect of crude oil on germination, growth and yield of broad bean was tested in contaminated soil. A series of soil pollution levels, ranged between $1 \%$ and $10 \%(\mathrm{w} / \mathrm{w})$ were prepared. The seed germination, vegetative growth and yield of broad bean were investigated. Low concentration of crude oil was found to stimulate the vegetative growth and increase the yield. High concentration of crude oil (4\% and above) reduced the germination percentage ,vegetative growth and yield. At concentrations of $8 \%$ \& $10 \%$, many seedlings had reduced growth and survival. Hydrocarbons accumulated in shoot and pods (seeds) were separated and monitored by quantitative gas chromatography (GC.). The residual n-alkanes and iso-alkanes of the saturates fraction were decreased with increasing the pollution levels. Lighter n-alkanes $\left(C_{10}-C_{20}\right)$ were found only in the shoots, while the higher carbon number n-alkanes $\left(\mathrm{C}_{20}-\mathrm{C}_{31}\right)$ were detected in both shoots and pods. The results suggested not to grow edible plants in areas subjected to low or high concentration of petroleum oil.

Key wards: Broad bean, germination, growth, Petroleum oil, yield.

\section{Introduction}

Petroleum oil represents a major problem in all oil producing countries. In recent years crude oil is viewed as an environmental contaminant potentially harmful to microorganisms, plants, animals and human health. The deleterious effects of oil are best seen on the flora, yet less conspicuous effect exerted on the animal community (woodwell, 1970) and bird metabolism (Leighton, 1993). The major sources of oil pollution come from pipline ruptures, tank failures, storage and transportation accidents which create hydrocarbon contamination (Bossert and Bartha, 1984). Occasionally on a very large scale, for example, the Iraqi invasion of Kuwait and firing more than seven hundred oil wells, resulted in spilling of millions of tons of crude oil in the surrounding areas. Wang and Bartha (1990) and Hegazy (1995) reported that soils contaminated with the hydrocarbons fail to support normal plant growth.

Many studies were conducted on the boidegradation of crude oil in Kuwait (AlGounaim et al., 1992; 1995,1998) and on the accumulation of heavy metals in some fruits and vegetables (McNulty et al., 1997). Previous studies in Kuwait (Hussain et al., 1995), revealed that the heavy metals exceeded the maximum acceptable level. Also Sallal (1995) stated that crude oil of Kuwait completely inhibited growth, photosynthesis and enzyme activity of Anasystic nidulans at a concentration of $4 \mathrm{ml} / \mathrm{L}$. 
Hitherto, very little research has been carried out on the effect of crude oil on higher plants in the Gulf region. This study was conducted to determine the influence of various concentrations of petroleum oil on germination, growth and yield of Vicia faba. The accumulation of some derivatives of crude oil (saturates, aromatics, and resins) in shoot and pods of the plant were determined.

\section{Material and Methods}

Sandy soil was collected from desert region of Kuwait (Ahmadi) and broad been seeds were obtained from the Agriculture Research Cetnter, Giza, Egypt.

Broad been seeds were planted in plastic pots (25cm diameter) each containing $10 \mathrm{~kg}$ air dried soil. Soils were mixed with petroleum oil (crude oil) in a series ranged between $1 \%$ and $10 \%(\mathrm{w} / \mathrm{w})$. Seeds were sown at rates of ten seeds / pot and irrigated by tap water. The plants were irrigated with a normal level so that the soil water content was always kept near field capacity during the whole experiment.

The experiment was carried out under natural fvironmental condition. The average daily temperature was $20^{\circ} \mathrm{C}$. Germination percentage was calculated. After full germination (two to three weeks after sowing) plants were thinned to five healthy seedlings per pots. The following growth criteria were recorded on individuals chosen at random: plant height, root lengh, fresh and dry weight of stem and roots.

\section{Soil}

Prior to cultivation, air dried soil was collected and sieved to remove all pebbles and gravels. Sieved soil were analyzed to determine its physical and chemical properties (Table 1). Soil tixture and total carbonates were determined according to Jackson (1962). The maximum water holding capacity was estimated by Hilgard pan box as described by Piper (1947). The $\mathrm{pH}$, electric conductivity (EC), soluble carbonate, bicarbonate, sulfate and organic carbon were estimated according to Hesse (1971). Mineral ions and sodium adsorption ratio (SAR) were measured using atomic absorption spectrophotometry following a $\mathrm{HNO}_{3}-\mathrm{H}_{2} \mathrm{O}_{2}$ digestion of the soil samples.

Table 1. Soil physical and chemical properties.

\begin{tabular}{|c|c|c|c|c|c|c|c|}
\hline \multicolumn{8}{|c|}{ Mechanical analysis (\%) } \\
\hline \multicolumn{2}{|c|}{$\begin{array}{c}\text { Coarse sand } \\
28.35\end{array}$} & $\begin{array}{l}\text { Fine sand } \\
62.20\end{array}$ & \multicolumn{2}{|r|}{$\begin{array}{l}\text { Very fine sand } \\
7.30\end{array}$} & $\begin{array}{c}\text { Silt + Clay } \\
1.57\end{array}$ & & \\
\hline \multicolumn{8}{|c|}{ Chemical analsysis } \\
\hline $\mathrm{PH}$ & \multicolumn{2}{|c|}{$\begin{array}{c}\text { EC Total carbonate } \\
\text { (m.mhos/cm) (\%) }\end{array}$} & \multicolumn{2}{|r|}{$\begin{array}{l}\text { Soluble carbonate } \\
\text { m.eq/l }\end{array}$} & \multirow{2}{*}{$\begin{array}{c}\text { Bicarbonate } \\
\text { m.eq/l } \\
0.2 \\
\end{array}$} & \multirow{2}{*}{$\begin{array}{c}\text { Sulfate } \\
\% \\
1.8 \\
\end{array}$} & \multirow{2}{*}{$\begin{array}{c}\text { Organic carbon } \\
\% \\
0.6 \\
\end{array}$} \\
\hline 8.52 & 3.75 & 31 & & Nil & & & \\
\hline \multicolumn{8}{|c|}{ Mineral ions , m. eq/l } \\
\hline $\mathrm{Na}$ & & $\mathrm{K}$ & $\mathrm{Ca}$ & $\mathrm{Mg}$ & SAR & & \\
\hline 17 & & 0.5 & 18 & 16 & 4.13 & & \\
\hline
\end{tabular}


Effect of Petroleum oil on the germination, growth and yield of broad bean plants

\section{Analysis of plant material}

\section{a. Determination of residual oil}

Air dried shoots and pods were dried for 3 days at $65^{\circ} \mathrm{C}$ in an electric oven. Two grams of the plant powder were mixed with anhydrous sodium sulfate and extracted with $200 \mathrm{ml}$ chloroform. Subsequently, the resideual oil was determined according to (Chaneau et al., 1995).

\section{b. Column chromatography}

The aliphatic, and aromatic hydrocarbons were determined by coloumn chromatography. The soluble part of the plant extract was evaporated and dissolved in the least amount of n-hexane. Silica Gel (ICN silica $100-200$ mesh) was heated at $130^{\circ} \mathrm{C}$ overnight, then cooled and mixed with n-hexane and poured in glass coloumn $(15 \mathrm{~cm}$ long, $1.7 \mathrm{~cm}$ diameter) and elluted by $60 \mathrm{ml}$-hexane.

The sample was placed at the head of the column and elluted successively with $60 \mathrm{ml}$ of n-hexane, benzene and methanol. The elluted fractions (aliphatics, aromatic, resins) were collected, evaporated and determined.

\section{c. Gas chromatography}

The evaporated fraction of n-hexane was eluted and analysed by gas chromatography. Gas chromatographic technique was used to identify the types of saturated aliphatic hydrocarbons in the sample, (SHIMADZU gas chromatography).

GC-14B was equipped with a direct injection part and a detector both set at $350^{\circ} \mathrm{C}$. The carrier gas was helium under $50 \mathrm{kPa}$. The temperature programming was $80-$ $300{ }^{\circ} \mathrm{C}, 3$ minutes intial temperature hold time, $10{ }^{\circ} \mathrm{C}$ temperature rise rate, 5 minutes final temperature and 3 minutes hold time.

\section{Results and Discussion Seed germination}

The results demonstrated that the rate of germination decreased with the increase of crude oil concentrations (Figure 1). The control seed germination reached $94.3 \%$, while the lowest germination percentage was about $3 \%$ at crude oil level of $10 \%$. It was observed that most of seeds germinated immediately after 4 or 5 days at the lowest concentrations of $1 \%, 2 \%$ and $4 \%$. Many seeds failed to germinated and/or had delayed germination to the tenth day, especially at high crude oil levels (8\%, 10\%). Many seedlings failed to continue its growth at high crude oil levels.

The above mentioned results agree with findings of other investigators. Klokk (1986) stated the soil polluted levels with petroleum oil gave a reduction in the germination frequency and vegetative growth of Festuca rubra and Trifolium repens; Also, Mackiewicz et al. (1982) reported that the soil polluted with crude oil had delayed germination and reduced growth in many crops. This delay or failure of seed germination is a result of the accumulation of high saturated hydrocarbons and/or due to the potential phytotoxicity of some crude oil constituents. 


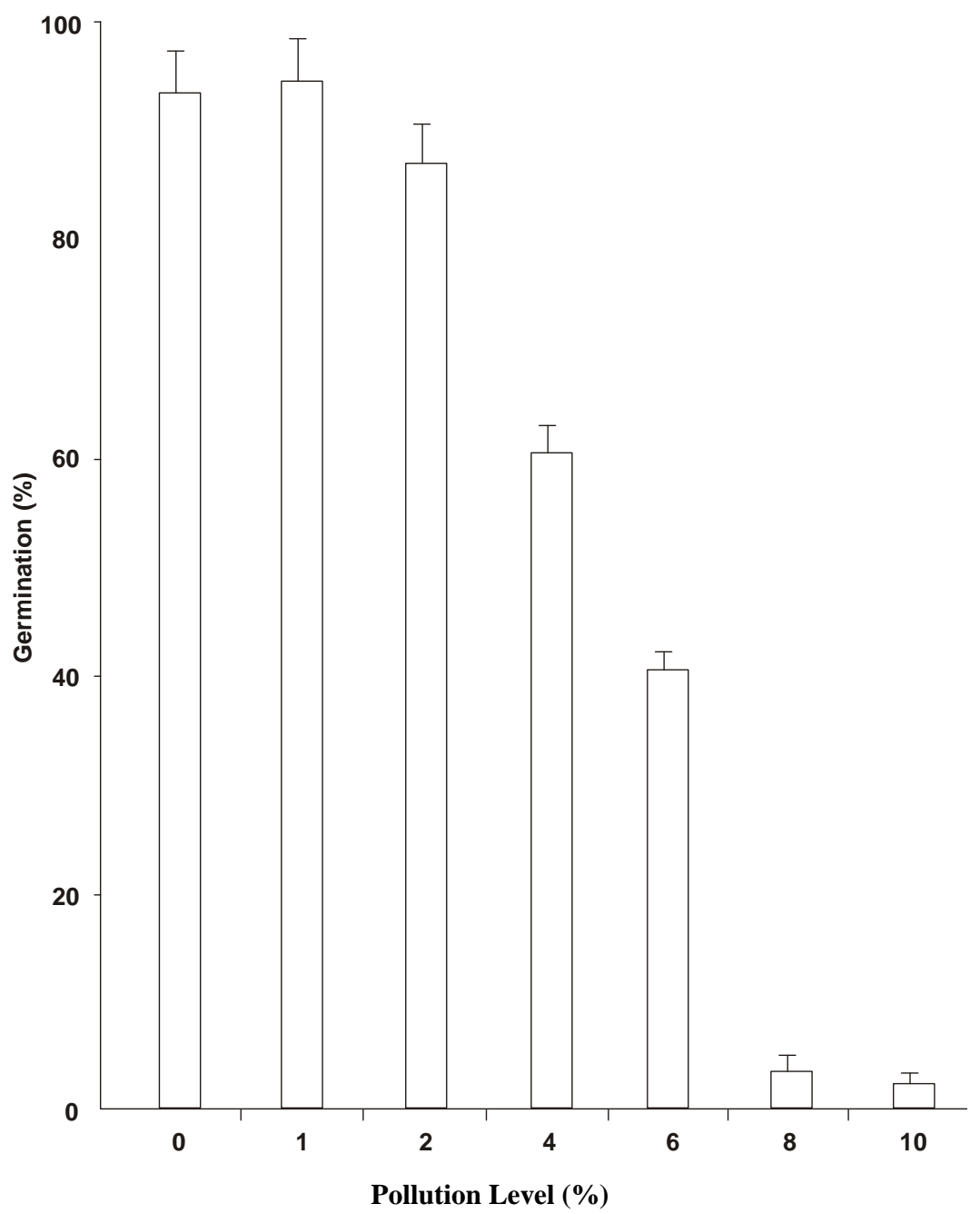

Figure 1. Effect of different concentrations of petroleum oil on seed germination of broad bean plants. Vertical lines are the standard errors of the means.

\section{Plant growth}

The height of mature plants was progressively decreasing with the increase of crude oil level. The plant height was $64.1 \mathrm{~cm}$ at the $1 \%$ level and decreased to $21.2 \mathrm{~cm}$ at the highest level of $10 \%$. Figure 2a indicating that maximum height of mature control plants was about three times higher than that at the lowest crude oil level. This may be due to some constituents of petroleum oil which may act as growth regulators. Ironically, very low hydrocarbon level, may stimulate plant growth. 

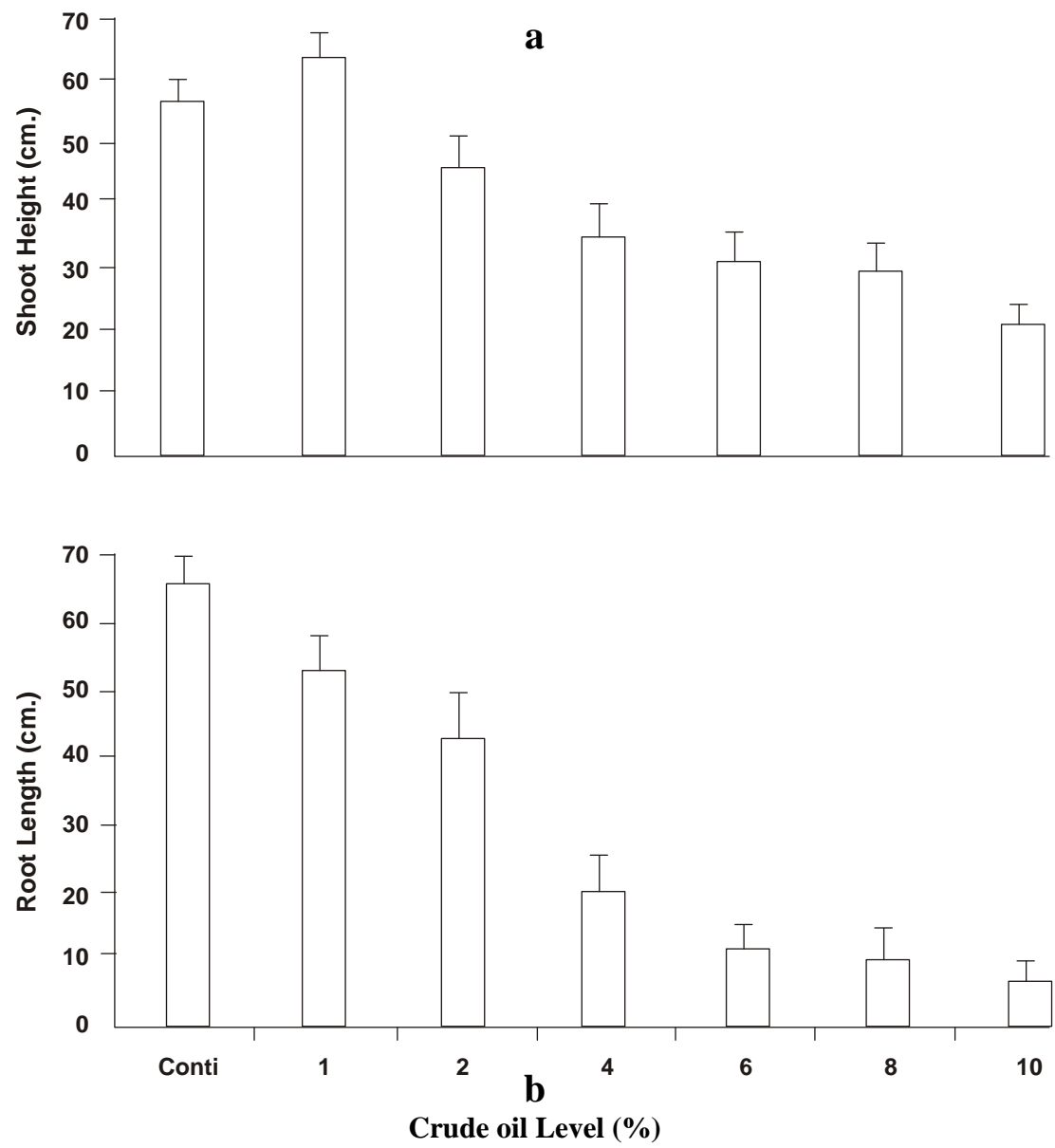

Figure 2. Effect of petroleum oil on plant height and root length of broad bean plants grown under different levels. Vertical lines represents the standard errors of the means.

Root system represent the part of the plant which is affected directly by crude oil. The root length decreased progressively with increase of pollution levels (Fig. 2b). The shortest root length of $6.41 \mathrm{~cm}$ was recorded at $10 \%$ crude oil level. It is ten times less than of the control.

Other studies (Huddleston and Meyers, 1978; Pal and Overcash, 1978; Kinako, 1981) revealed, that the application of oil wastes to soil in moderate amount (1-5\% in the upper $15 \mathrm{~cm}$ soil layer) usually has less-deleterious effects on the plant community than do the large-scale accidental spills.

It is clear from Table 2 that the mean fresh and dry weight of stem per plant decreased with the increase of soil crude oil levels. At the lowest level of soil pollution, the fresh and dry weights of the stem per individual plant was higher than that of the other treatments. The effect of lowest level (1\%) on fresh and dry weight of stem / plant was 
nigligible as compared with untreated soil (control). Meanwhile, the increase in soil pollution levels caused a reduction in fresh and dry weight of stem per plant.

Table 2. Effect of different concentration of petroleum oil on fresh \& dry weight of stems, roots and leaves of broad been plants

\begin{tabular}{|l|c|c|c|c|c|c|c|}
\hline Treatment & Cont. & $1 \%$ & $2 \%$ & $4 \%$ & $6 \%$ & $8 \%$ & $10 \%$ \\
\hline & 7.24 & 8.11 & 5.45 & 3.52 & 2.34 & 2.35 & 1.97 \\
Fresh weight of stem/plant g. & \pm & \pm & \pm & \pm & \pm & \pm & \pm \\
& 0.35 & 0.85 & 0.49 & 0.22 & 0.38 & 0.37 & 0.27 \\
\hline & 1.13 & 1.37 & 0.83 & 0.66 & 0.43 & 0.25 & 0.20 \\
Dry weight of stem/plant g. & \pm & \pm & \pm & \pm & \pm & \pm & \pm \\
& 0.07 & 0.25 & 0.19 & 0.06 & 0.06 & 0.04 & 0.03 \\
\hline & 5.99 & 7.27 & 4.35 & 3.07 & 1.66 & 1.22 & 0.95 \\
Fresh weight of root/plant g. & \pm & \pm & \pm & \pm & \pm & \pm & \pm \\
& 0.94 & 1.24 & 0.74 & 0.42 & 0.46 & 0.07 & 0.07 \\
\hline & 6.05 & 6.93 & 4.21 & 2.71 & 1.45 & 1.06 & 0.66 \\
Dry weight of root/plant g. & \pm & \pm & \pm & \pm & \pm & \pm & \pm \\
& 0.84 & 1.24 & 0.30 & 1.33 & 0.19 & 0.07 & 0.30 \\
\hline & 0.85 & 0.76 & 0.76 & 0.51 & 0.38 & 0.19 & 0.13 \\
Dry weight of leaves/plant g. & \pm & \pm & \pm & \pm & \pm & \pm & \pm \\
& 0.17 & 0.04 & 0.04 & 0.03 & 0.04 & 0.03 & 0.04 \\
\hline
\end{tabular}

The fresh and dry weight of root per individual plant showed the same trend as the fresh and dry weight of stem (Table 2). The maximum value was recorded at lewest level of soil pollution (7.27 $\mathrm{g}$ for fresh weight and $1.04 \mathrm{~g}$ for dry weight).

The reduction of root and shoot length as well as the fresh and dry weight of stem and root, may be due to presence of many toxic compounds and/or reduction of soil aeration due to oil contamination. Also, the low boiling component of petroleum oil may exhibit a high degree of contact toxicity to the tender portion of the plant parts. These results agree with the findings of many investigatiors (McGill et. al., 1981, Hunt, et al., 1973 and Fattah \& Wort, 1970). They reported that, petroleum pollution of soil has strong negative effect on plant growth especially the root system. Also, the percolation of crude oil through soil reduce aeration subsequently, the root growth. The diffusion of petroleum toxic components may selectively inhibit or prevent many metabolic processes. The most toxic components may volatilize or become immobilized by sorption to soil organic matter, although partial degradation of hydrocarbons may emulsify and release more harmful substances into the soil and root system. Neverthless, the indirect effects of petroleum pollutants in soil include oxygen deprivation of plant root, because of exhaustion of soil oxygen by hydrocarbon degrading microorganisms. Such anaerobic conditions may bing about the microbial generation of phytotoxic compounds such as $\mathrm{H}_{2} \mathrm{~S}$.

The numbers and fresh weights of leaves are important factors affecting the assimilation area of the plant and consequently the vegetative growth. The highest fresh and dry weights of leaves per individual plant were observed at the lowest level of pollution (Table 2). At the highest levels of pollution (8 \& 10\%), the fresh and dry weights of leaves per plnat were less than sixth of the control. This phenomenon may be referred to inhibition of many metabolic processes as a result of diffusion of many toxic 
Effect of Petroleum oil on the germination, growth and yield of broad bean plants

components and volatilization of aromatic compounds which affect leaf development and growth.

\section{Plant Yield}

The yield of dry pods per plnat exhibited great variation under pollution levels. Under the high levels of crude oil, the yield dropped to about $1 \%$ compared to the control or the lowest level (1\%). The highest yield was recorded at $1 \%$ level (8.31 g/plant) and the lowest yield was recorded at $10 \%$ level (1.31 g/ plant). It is evident that there is a remarkable decrease in the dry weight of pods per plant with the increase of crude oil levels (Fig.3). The results of plant yield are in agreement with the findings of other investigatior. Klokk, (1986) and Brown et al. (1982) stated that petroleum oil pollution and sludges gave a reduction in gemination frequence and vegetative growth as well as the net production of shoot system and yield. Also, Baldwin (1992) demonstrated a significant decrease in nitrate concentrations of amended greenhouse soil to which crude oil was applied.

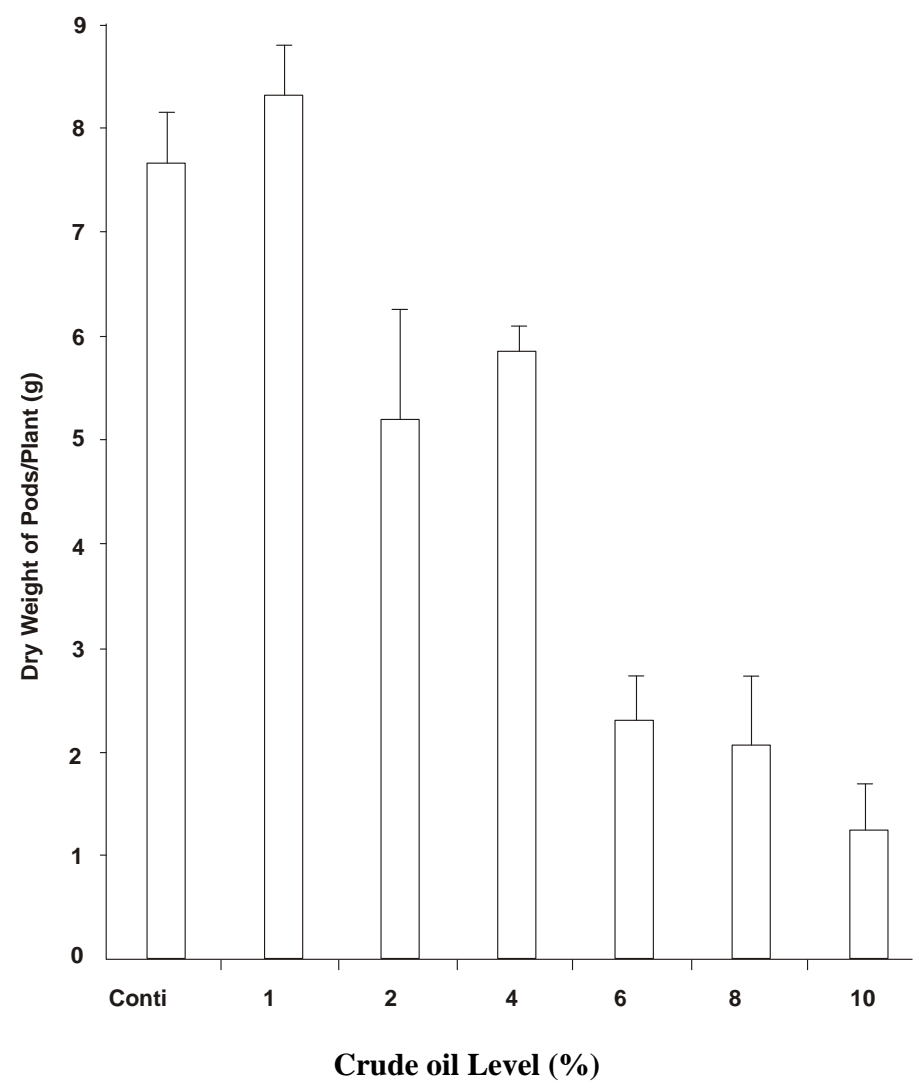

Figure 3. Effect of petroleum oil on Yield of broad bean plants. Vertical lines represents the standard errors of the means. 
Although plant growth of corn, measured as dry shoot weight, proportionately declined with increasing amounts of crude oil added.

\section{Residual oil and its fractions}

As shown in Tables 3 \& 4, the saturates were decreased with the increase of oil concentration in the shoot and pods. At the lowest crude oil level (1\%), the saturates were about two times that of $2 \%(0.0183)$, and three or four times that of $6 \%$ or $8 \%(0.0048)$.

Table 3. Percentage of saturates, aromatics, resin and asphaltine (by weight) in shoot of broad bean, relatively to the amount of residual oil.

\begin{tabular}{|c|c|c|c|c|}
\hline $\begin{array}{c}\text { Polluted } \\
\text { Levels (\%) }\end{array}$ & Fractions & $\begin{array}{c}\text { Wt. of } \\
\text { Fractions (g) }\end{array}$ & $\begin{array}{l}\text { \% Wt. of oil } \\
\text { residue }\end{array}$ & $\begin{array}{c}\text { \% of oil residue } \\
\text { g./sample }\end{array}$ \\
\hline \multirow{4}{*}{ Shoot System } & Saturates & 0.0092 & 23.958 & \multirow{4}{*}{1.920} \\
\hline & Aromatics & 0.0060 & 15.625 & \\
\hline & Resins & 0.0105 & 27.343 & \\
\hline & Residue & 0.0127 & 33.073 & \\
\hline \multirow{4}{*}{$1 \%$} & Saturates & 0.0183 & 32.447 & \multirow{4}{*}{2.765} \\
\hline & Aromatics & 0.0059 & 10.461 & \\
\hline & Resins & 0.0254 & 45.035 & \\
\hline & Residue & 0.0068 & 12.056 & \\
\hline \multirow{4}{*}{$2 \%$} & Saturates & 0.0097 & 20.293 & \multirow{4}{*}{2.293} \\
\hline & Aromatics & 0.0074 & 15.481 & \\
\hline & Resins & 0.0085 & 17.782 & \\
\hline & Residue & 0.0222 & 46.443 & \\
\hline \multirow{4}{*}{$4 \%$} & Saturates & 0.0071 & 16.745 & \multirow{4}{*}{2.060} \\
\hline & Aromatics & 0.0062 & 14.623 & \\
\hline & Resins & 0.0246 & 58.019 & \\
\hline & Residue & 0.0045 & 10.613 & \\
\hline \multirow{4}{*}{$6 \%$} & Saturates & 0.0048 & 30.188 & \multirow{4}{*}{1.554} \\
\hline & Aromatics & 0.0061 & 38.365 & \\
\hline & Resins & 0.085 & 52.201 & \\
\hline & Residue & 0.0033 & 20.754 & \\
\hline \multirow{4}{*}{$8 \%$} & Saturates & 0.0048 & 19.917 & \multirow{4}{*}{2.226} \\
\hline & Aromatics & 0.0056 & 23.236 & \\
\hline & Resins & 0.0058 & 24.066 & \\
\hline & Residue & 0.0079 & 32.780 & \\
\hline
\end{tabular}


Effect of Petroleum oil on the germination, growth and yield of broad bean plants

Table 4. Percentage of saturates, aromatics, resin and asphaltine (by weight) in pods or seeds of broad bean, under different levels of crude oil in the soil.

\begin{tabular}{|c|c|c|c|c|}
\hline $\begin{array}{c}\text { Crude oil } \\
\text { Levels (\%) }\end{array}$ & Fractions & $\begin{array}{c}\text { Wt. of } \\
\text { Fractions (g) }\end{array}$ & $\begin{array}{l}\% \text { Wt. of oil } \\
\text { residue }\end{array}$ & $\begin{array}{c}\% \text { of oil residue } \\
\text { g./sample }\end{array}$ \\
\hline Pods or seeds & $\begin{array}{c}\text { Saturates } \\
\text { Aromatics } \\
\text { Resins } \\
\text { Residue }\end{array}$ & $\begin{array}{l}0.0038 \\
0.0013 \\
0.0028\end{array}$ & $\begin{array}{c}198 \\
65.00 \\
140\end{array}$ & 0.173 \\
\hline $1 \%$ & $\begin{array}{c}\text { Saturates } \\
\text { Aromatics } \\
\text { Resins } \\
\text { Residue }\end{array}$ & $\begin{array}{l}0.0048 \\
0.0055 \\
0.0097 \\
0.0019\end{array}$ & $\begin{array}{l}26.193 \\
30.387 \\
53.591 \\
10.497\end{array}$ & 1.609 \\
\hline $2 \%$ & $\begin{array}{c}\text { Saturates } \\
\text { Aromatics } \\
\text { Resins } \\
\text { Residue }\end{array}$ & $\begin{array}{l}0.0025 \\
0.0025 \\
0.0098 \\
0.0015\end{array}$ & $\begin{array}{l}19.084 \\
17.557 \\
74.809 \\
11.450\end{array}$ & 1.280 \\
\hline $4 \%$ & $\begin{array}{c}\text { Saturates } \\
\text { Aromatics } \\
\text { Resins } \\
\text { Residue }\end{array}$ & $\begin{array}{l}0.0036 \\
0.0062 \\
0.0074 \\
0.0057\end{array}$ & $\begin{array}{l}31.304 \\
53.130 \\
64.348 \\
49.565\end{array}$ & 1.101 \\
\hline $6 \%$ & \multicolumn{4}{|c|}{ Not detected } \\
\hline $8 \%$ & \multicolumn{4}{|c|}{ Not detected } \\
\hline
\end{tabular}

The aromatics, resins and residues exhibited irregular trends from one level of crude oil to another. Generally the accumulation of petroleum oil or its derivatives inside the plant tissues will affect the growth, all metabolic processes and yield. The adverse efffects were common and observed on individuals at high concentration of crude oil levels (6\% \& 8\%). The reduction in accumulation of low boiling components of petroleum (saturates and aromatics) under high levels of pollution may be referred to high degree of toxicity.

\section{Gas chromatographic analysis}

The saturates (n-alkanes) profile accumulated in different parts of the plants were evaluated by gas chromatographic analysis (Figures 4 and 5). The GC analysis revealed a significant accumulation of n-alkanes $\left(\mathrm{C}_{13}-\mathrm{C}_{31}\right)$ in shoot. A detectable regular increase of the amount of n-alkanes in the shoot was observed, with the increase of the oil content of soil (w/w,\%) up to $6 \%$ and attained constant values at $8 \%$. Maximum amounts, of absorbed n-alkanes by plant, were noticed at $6 \%$ and $8 \%$.

It is worth mentioning that lighter n-alkanes $\left(\mathrm{C}_{10}-\mathrm{C}_{20}\right)$ were nearly found only in the shoot. However, higher carbon nuber $\left(\mathrm{C}_{20}-\mathrm{C}_{31}\right)$ was detected in both shoot and pods. This indicates that light n-alkaus were fully absorbed by shoot (stem and leaves). Regarding to the GC profile of n-alkanes accumulated in pods (Fig. 4,5), there was a remarkable accumulation of most of heavier n-alkanes $\left(\mathrm{C}_{20}-\mathrm{C}_{29}\right)$, while lighter n-alkanes $\left(\mathrm{C}_{10}-\mathrm{C}_{20}\right)$ were not accumulated. The highest amount $n$-alkaues were recorded in pods or 
seeds at $1 \%$ of crude oil content, while the minimum amount was found at $4 \%$. This may be attributed to the high amount of n-alkanes accumulation in the plant shoot part (Figures 4 and 5).


Figure 4. Gas chromatographic analysis of the n-alkanes extracted from shoot of broad bean grown at various pollution levels of petroleum oil. (a, control; b: $1 \%$, c: $2 \%$, d: $4 \%$, e: $6 \%$, f: $8 \%, w / w)$ 
Effect of Petroleum oil on the germination, growth and yield of broad bean plants
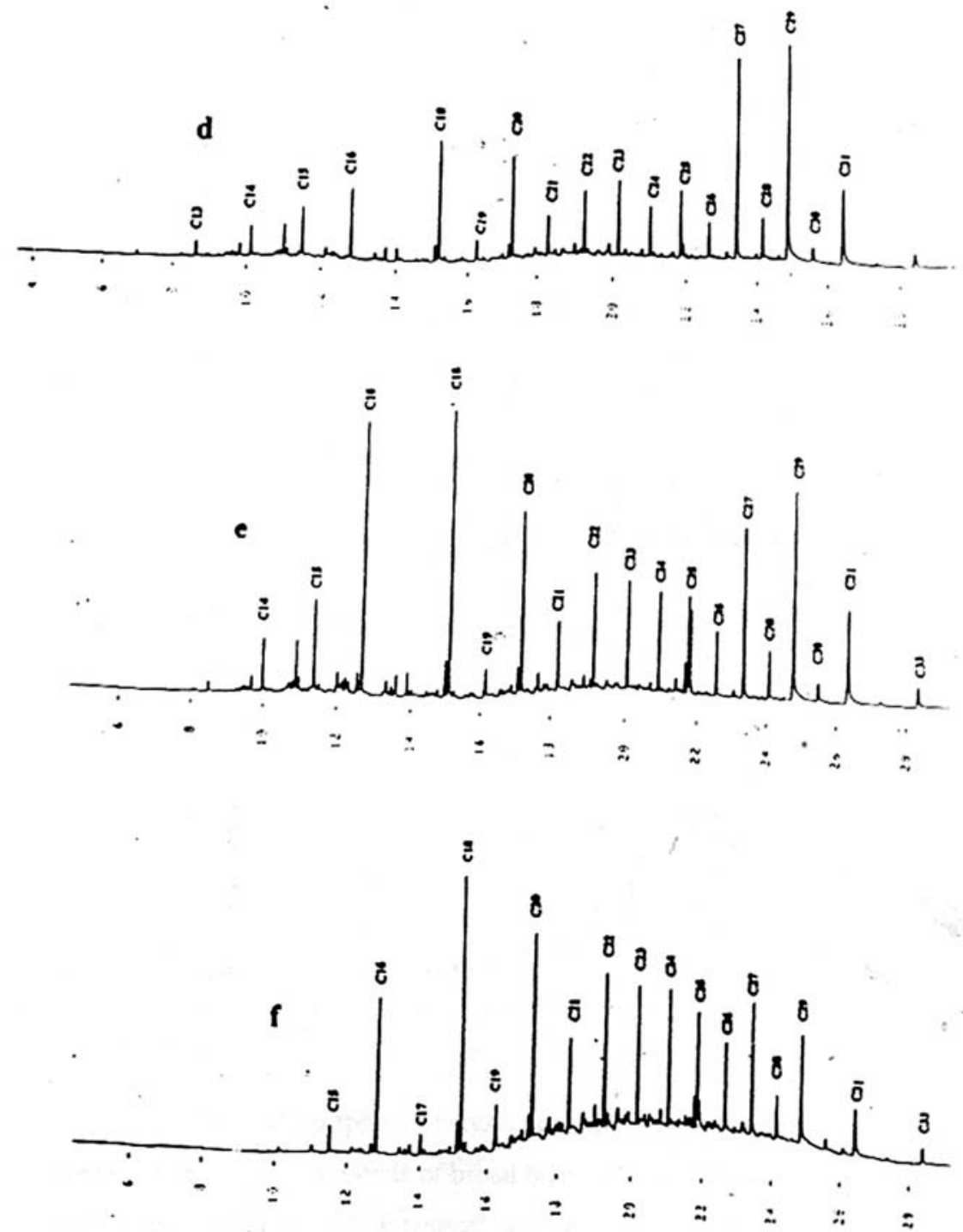

Figure 4, continued 
H. El- Tantawy and A. El- Hilaly
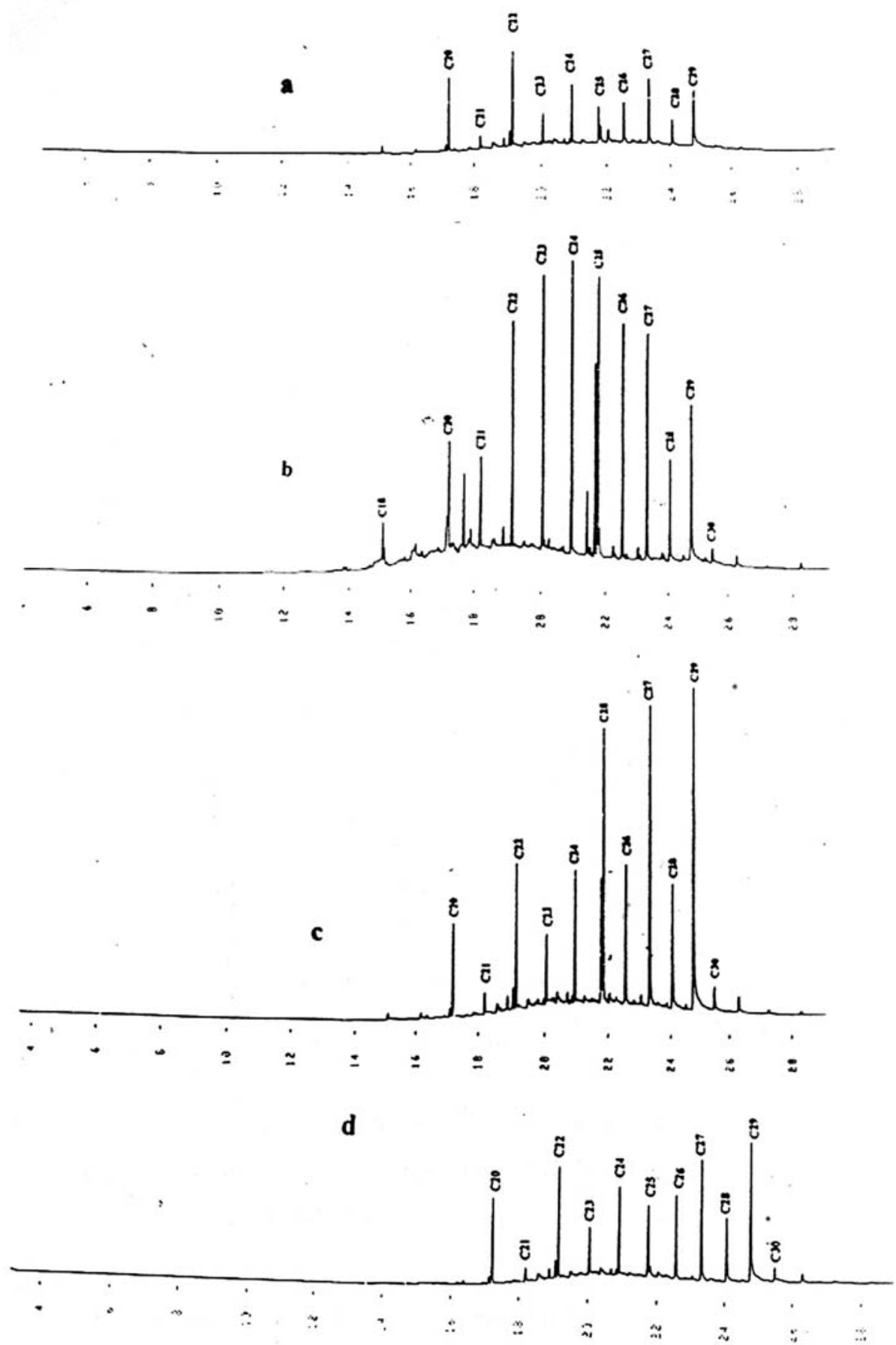

Figure 5. Gas chromatographic analysis of the n-alkanes extracted from pods or seeds of broad bean grown at various pollution levels of crude oil (a: control, b:1\%, c: $2 \%, d$ : $4 \% \mathrm{w} / \mathrm{w}$ ) 
These results are in agreement with many investigatior. For example Beattie et al. (1989) reported that crude oil phytotoxicity may be severe enough to reduce yield with or without causing visible injury. Also phytotoxicity of oil is primarily related to their unsaturated hydrocarbon content and the molecular weight of their molecules which increases with distillation temperature and n-paraffin carbon number.

Generally, petroleum oil pollution has strong negative effect on plant metabolism. The mode in which petroleum acts on plants is complex and involves both contact toxicity and indirect deleterious effects mediated by interactions of the petroleum with the abiotic and microbial components of soil. The low - boiling components of petroleum exhibit a high degree of contact toxicity to the tender portion of plant shoot and root. Contact toxicity occurs primarily by the solvent of low - boiling hydrocarbons on the lipid structures of the plant cell membranes. The order of toxicity is monoaromatics $>$ olefins and naphthalenes $>$ paraffins. Within each class toxicity is positively correlated to increasing polarity and inversely correlated to increasing molecular weight (McGill et al., 1981).

In conclusion, it is apparent that the toxic effects of crude oil are harmful to plants as well as to human and beings who uses them as food.

Therefore, it is not suggested to grow crop plants in areas subjected to crude oil pollution. Moreover, further studies are needed to clarify the phytotoxic effects of crude oil on plants from different ecological groups.

\section{References}

Al-Gounaim, M. Y.; Diab, A. \& El-Shinawi, K. 1992. Effect of petroleum oil spilled in the desert of Kuwait on the microbial flora of the soil. Proceeding of third world academy of science, Fourth general conf., Kuwait 23-26 Nov.

-; Diab A; Al-Abdalla, R. \& Al-zamil, N. 1995. Effect of petroleum oil pollution on the microbioligal population of the desert soil of Kuwait. Arab Gulf. $J$. Sci., Res., 13(3):623-672.

- \& Diab, A. 1998. Effect of the inoculation of Aspergillus terries - an oil degrading fungus on the microbial community and biodegradation activity of a desert soil sample, from Kuwait. African J. of Mycology and biotechnology Vol. 6(1): 9-25.

Baldwin, I. L. .1992. Modification of the soil flora a induced by application of crude petroleum. Soil. Sci. 14:465-477.

Beattie, G. A. C.; Roberts, E. A.; Rippon, L. E. \& Vanhoff, C. L. 1989. Phytotoxicity of petroleum spray oils to Valencia orange, Citrus sinensis (L.) Osbeck, in New South Wales. Australian Journal of Experimental Agriculture, Vol, 29:273-282.

Bossert, I. \& Bartha, R. .1984. The fate of petroleum in soil ecosystems. In Petroleum Microbiology (R. M. Atlas, Ed), pp. 453-473. Macmillan New York.

Brown, K. W.; Barwand, J. Thomas, C. \& Evans, B. 1982. Impact of simulated land treatment with oily sludges on ryegrass emergence and yield. Agron. Jour. Vol. 74(2): 257261.

Chaineau, C. H.; Morel. J. L. \& Oudot, J. 1995. Microbial degradation in soil microcosms of fuel oil hydrocarbons from drilling cuttings. Environ, Sci. Technol. 29:1615-1621.

Fattah, Q. H., \& Wort, D. J. 1970. Effect of light and temperature on stimulation of vegetative and reproductive growth of bean plant by naphthenates. Agron. J. 62:567-577. 
Hegazy, A.K. 1995. Phytomonitoring and management of tar piles on the Qatari coastal marshes, arabian gulf. Environmental pollution. 90(2):187-190.

Hesse, P. R. 1971. A Textbook of Soil Chemical Analysis. William Clowes ND Sons Limited. London.

Huddlestion, R. L. \& Meyers, J. D. 1978. Treatment of refinery oil wastes by land farming: National meeting of american, chem. Eng. Philadelphia.

Hunt, P. G.; Rickard, W. E.; Deneke, F. J.; Koutz, F.R. \& Murman, R. P. 1973. Terrestrial oil spills in Alask. Environmental effect and recovery.

Husain, A.; baroon, Z.; Al-Khalafawi, S.; Al-Aati \& Sawaya, W. 1995. Heavy metals in fruits and vegetables grown in Kuwait during the oil well fires. Arab Gulf J. Sci. Res. 13(3):535-542.

Jackson, M. L. 1962. Soil Chemical Analysis. Constable \& Co. Ltd. London.

Kinako, P. D. S. 1981. Short - term effect of oil pollution on species number and productivity of a simple terrestrial ecosystem. Environ. Pollut. Ser. A26:87-91.

Klokk, T. 1986. Effect of oil and dispersant on the Trifolium repens. N TIS Code : PC AC3/MF AOIP. 15.

Leighton, F. A. 1993. The toxicity of petroleum oils to birds. Environment 1(2):92-112.

Mackiewicz, J. 1982. Response of crops to soil pollution with crude oil. Zeszyty Naukowe Akademii Rolniczo No. 11:191-200.

McGill, W. B.; Rowell, M. J., \& Westlake, D. W. S. 1981. Biochemistry, ecology, and microbiology of petroleum complements in soil. In: Soil Biochemistry (E.A. Paul and J.N. Ladd, eds.) Vol. 5, pp. 229. Marcel Dekker, New York.

McNulty, D.; Alloway, J.B. \& Aitken, N.M. 1997. Plant availability of heavy metals in soils previously amended with heavy applications of Sewage sludge. J. Sci. Food Agric., 73:446-454.

Pal, D. \& Overcash, M. R. 1978. Plant - soil assimilative capacity for oil. National meeting of american institute of chem. Eng. Philadephia.

Piper, C. S. 1947. Soil and Plant Analysis. Intersci. Pub. Inc. New York.

Sallal, A. J. 1995. Effect of crude oil and benzene on growth, Photosynthesis and glycollate dehydrogenase of Anasystic nidulans. Arab Gulf J Scient Res 13(2):357-367.

Wang, X. and Bartha, R. 1990. Effects of bioremediation on residues, activity and toxicity in soil contaminated by fuel spills. Soil. Biochem, (22)4: 501-505.

Woodwell, G. M. 1970. Effect of pollution on the structure and physiology of ecosystems. Sccience 168:429-433. 